\title{
LOAN AGREEMENTS - POINTS OF LEGAL INTEREST PETER STONE:
}

\begin{abstract}
This paper deals with legal points ro be noted by a low'yer engoped in the drajiung of a ioan apreement oerween e mapor Cenedian chertered bank tending in Caneda and one corporate borrower engeged in ine oil and gas business.
\end{abstract}

\section{WHY A LOAN AGREEMENT?}

From the point of view of the borrower, a loan agreement is. in most cases. unnecessary. The process of preparing a loan agreement has the advantage for the borrower that by the time the agreement is signed, both borrower and lender ought to have a clearer understanding of their agreement than when they started the process; similarly, both parties ought to understand better at the end than at the beginning which points are of importance to the other and which have less significance. Generally speaking, however, it remains true that the borrower's needs could be met for all but the largest and most complex loans by a two or three page letter agreement.

The difference between what would satisfy the borrower and what it actually takes to make a loan agreement is comprised of material required to protect the lender. It is, therefore, easy to see that a loan agreement is primarily a document drafted to protect the lender. I ask you to bear this in mind if in what follows I seem to be preoccupied with the point of view of the lender.

\section{COMMITMENT LETTERS}

The common practice in loans which become the subject of loan agreements is for the lender to write a commitment letter to the borrower, a copy of which the borrower signs and returns so as to constitute a letter agreement.

In my experience, it is not common for lawyers to be involved either for the lender or for the borrower when commitment letters are drawn up.

Commitment letters are frequently couched in bankers' shorthand terminology, and they also frequently omit many provisions which a lawyer would regard as important from the banker's point of view. Commitment letters can. however, constitute binding contracts: see First City Investments Lid. v. Fraser Arms Hotel Lid.' and Dot Developments Lid. v. Fowler. ${ }^{2}$

The Fraser Arms case is instructive on a number of points. The British Columbia Court of Appeal applied the analogy of a contract for sale of lands (where the essential terms are only the parties, the property and the price) in deciding what are the essential terms which must be included in a commitment letter so as to permit the Court to gather the intention of the parties from the "four corners of the agreement", and so enforce the commitment letter by implying whatever essential terms are not expressly stipulated. The Court held that where the commitment letter contains a provision requiring the borrower to provide such documents as the lawyers for the lender may reasonably require, failure to agree on the form of a mortgage which is to be given

- Parner. Mclaws and Company, Calgary. Albena.

I. (1979)6 W.W.R. 125 (B.C. C.A.).

2. (1980) 118 D.L.R. (3d) 371 (B.C. S.C.). 
pursuant to the commitment letter does not render the commitment letter itself unenforceable. In that case, the lender was able to recover from a proposed borrower the balance of a commitment fee payable under a commitment letter where the proposed borrower failed to go through with the loan arrangement because of a title defect.

A second point to be noticed about the Freser Arms case is the importance of a clause specifying that documents will be prepared in accordance with the requirements of the lender's solicitors. The borrower argued that the lender's solicitors could not insert in the mortgage documents which they prepared for signature by the borrower terms (e.g. payment of taxes by mortgagee, acceleration of entire principal sum on default in paying one instalment, events of default clause) which were not specifically set out in the commitment letter. The Court rejected this contention, implying that the lender's solicitors could insert any reasonable provisions in a case where the commitment letter contains a clause empowering them to do so. In reaching this decision, the British Columbia Court of Appeal gave as its view that terms which most lenders would regard as important (e.g. covenants to insure in favour of mortgagee, acceleration of the entire principal sum on default in paying one instalment, right of mortgagee to take immediate possession on default) are not within the category of essential terms that a Court will imply into the agreement where the commitment letter is silent on those terms. A lender who fails to put into a commitment letter a provision similar to what is mentioned above, therefore, runs the risk of finding himself bound to advance under terms which afford him far less protection than is customary. The question whether or not a lender can be compelled by means of specific performance to make an agreed advance is dealt with below.

A third point which was raised indirectly by the Fraser Arms case is the manner in which "commitment fees" are to be stipulated for by the lender. It is customary for lenders to take such fees, and one difficulty from the point of view of the lender is to avoid the "fee" being treated as a penalty, and. consequently, being irrecoverable by the lender. In the Fraser Arms case, the fee was stated to be payable "for the analysis of the feasibility of the loan and arranging the loan"; it is noteworthy that counsel for the proposed borrower does not appear to have argued the question whether the commitment fee amounted to a penalty, notwithstanding that the commitment fee was approximately one and one-half percent of the total amount of the loan.

\section{EXTENT TO WHICH AN AGREEMENT TO BORROW AND LEND IS ENFORCEABLE}

A question which is central, both to commitment letters and to loan agreements, is the enforceability of the commitments by the borrower and the lender which are contained in those documents.

This point is dealt with in Two Hills Rental Properties Ltd. v. First City Trust Company, ${ }^{3}$ a decision of the Alberta Court of Queen's Bench. In that case, the defendant gave a qualified commitment to advance mortgage monies at a future date at a fixed interest rate. The defendant elected on that date not to advance because interest rates had risen in the period between the commitment 
being made and the date fixed for advance. The commitment letter contained a provision that "neither the preparation nor the regiștration of any of the documents contemplated by this letter shall bind" the lender to advance monies, and the morrgage prepared by the lender's solicitors contained a similar provision. Wachowich $J$. found that, in view of the above provisions. neither the commitment letter nor the mortgage imposed an obligation on the lender to advance.

Notwithstanding that First City had given an interim lender an assurance that First City would advance on the specified date, which assurance was sufficiently strong to convince the interim lender that a written commitment to advance from First City was unnecessary, Wachowich J. also found that the representation made by First City to the interim lender was not sufficient to waive First City's rights under the commitment letter and the mortgage, because the representation amounted only to "a statement that [First City] did not foresee any problems" in making the advance on the stipulated date. His Lordship held that "This does not constitute a promise to advance funds".

The decision is the more surprising because the Court stated that the defendant's conduct "although legal, in [the Court's] view lacks all of the elements of good faith that ought to exist in such business dealings, and it is this type of conduct which brings the financial institutions into disrepute". The case shows that, on occasion, strict "law" will be enforced by the Courts in circumstances where one might suppose that equity would find a way to intervene. From the point of view of a lender, the case points out the value of the inclusion of a "no obligation to advance" clause.

The Two Hills Rental Properties case raises a second and more fundamental question, namely, whether a loan commitment is enforceable by specific performance. The part of the decision which relates to loan commitments is obiter dicta, because His Lordship found that there was no such commitment in the case before him and because the plaintiff was not asking for specific performance, but it is nonetheless interesting for that. Wachowich J. quoted Laskin J. A. (as he then was) in Frankel Structural Steel Ltd. v. Goden Holdings Lid. ${ }^{4}$ where, citing Western Wagon and Property Co. v. West ${ }^{5}$ and Partridge v. Winnipeg Investment Co. Lid. ${ }^{6}$ Laskin J. A. said:

\footnotetext{
It is wefl-astablished law that a mortgagor cannos ordinarily compel the advance of money promised on the advance of realiy ... failure (by the lender to advence) would in ordinary cases (there may well be exeeptions). ave rise only to a chim for any difference in the cost of the comernplated loan.
}

The principle to which Laskin J. A. referred dates back at least to Rogers v. Challis 7 and Sichel v. Mosenthal, 8 both of which dealt with unconditional agreements to borrow and lend money. The first case stands for the proposition that the borrower cannot be compelled by specific performance to accept the loan, and the second for the corollary that the lender cannot be compelled by specific performance to make a loan. The reasoning of the Court

4. [1969] 2 O.R. 221: ajde [1971] S.C.R. 250.

5. [1982] । Ch. 271 .

6. [1921] | W. W.R. 839 a 853 (S.C.C. per Anglin. J.).

7. (1859) 27 Beav. 175.

3. 11862$) 30$ Beav. 371 . 
in both cases was that a plaintiff could only obtain specific performance where his remedy in damages was "inadequate or defective". The Court stated that there could be no such difficulty where the wrong complained of is a failure to advance or take money, because the amount of damages suffered would be "a mere matter of calculation". The principle was confirmed by the Privy Council in Larios v. Bonany y Gurery ${ }^{9}$ and in Western Wagon and Property $C o$. v. West. 10 The latter case held that an assignee of a commitment to lend cannot enforce the assignment against the lender because the lender could not have been compelled to advance to the assignor. The case further held that a lender who advances to an assignor despite the lender having received notice of the assignment cannot be compelled to repeat the advance in favour of the assignee; the assignee stands in the place of the assignor who, having received the advance, has suffered no damage.

Notwithstanding the antiquity of the rule and its adoption by the Supreme Court of Canada in Partridge v. Winnipeg Investment Co. Ltd. " it seems clear that the Courts may develop the implication contained in the statement of Laskin J. A., cited above, that in cases which are not "ordinary" the rule will not be followed. The statement of Laskin J. A. itself contains an implied limit to the rule which is not justified by the earlier cases, namely, that the rule oniy applies to mortgage advances. Obiter dicta in two Ontario cases cited in the Two Hills case, namely, Reid v. Garnet B. Hallowell Ltd 12 and Morguard Trust Co. v. 100 Main Street East Lid. 13 indicate that the rule may be subject to modification where the action of the lender is "capricious, arbitrary and selfish". Wachowich J. did not indicate any disagreement with these cases.

There are clear policy reasons for refusing to apply the rule inflexibly. Loan commitments of the type contained in a complex loan agreement are a result of many hours of effort on the part of both borrower and lender and may form the basis on which many other commitments are made by both parties. To justify a refusal to enforce a loan agreement against either party in such circumstances on the ground that the damages suffered by a refusal to honour the agreement are "a mere matter of calculation" would be a gross oversimplification and a grave injustice. Until the position is clarified, however, lawyers who prepare loan agreements and whose clients intend them to be specifically enforceable, should incorporate into those agreements terms (e.g.: that specific performance is to be available) which will encourage the Courts to give effect to that intention.

\section{PARTIES AND THEIR CAPACITY}

Even in the basic situation of one chartered bank and one corporate borrower. certain questions about the capacity of the parties arise. Section 173(1) of the Bank Act ${ }^{14}$ states that "a bank may engage in and carry on such business generally as appertains to the business of banking", and there follows an enumeration of various powers which is expressly stated to be without limit

9 SL.R.P.C. 346.

10. Supre n. 5

11. Supre n. 6.

12. (1978) 10 R.P.R. 308 (Ont. S.C).

15 unreported. 16 Mareh 1978. Ont. Div. Cl.

If S.C. $1980-81-82-83$. c. 40. 
to the generality of the opening statement. Specific restrictions on the scope oi a bank's activities are set out in Section 174.

The scope of the "business of banking" was considered by the Manitoida Court of Appeal in Central Computer Services Lid. and Comcheg Services Limited v. Toronto Dominion Bank. ${ }^{15}$ The case confirms that there is 70 definition of the "business of banking", and that it is unlikely that the Courts will ever attempt a comprehensive definition of banking. One of the Justices oi Appeal quoted Lord Denning: "Like many other beings, a banker is easier to recognize than to define".

The case concerned two services of the Toronto Dominion Bank. a computer billing service and a computer-assisted accounting service, which. inter alia. offered to prepare profit and loss statements and balance sheets ior customers. The two Justices of Appeal who were in the majority took quite different approaches in determining what is the "business of banking". Monnin J. A. regarded the matter as a question of fact. His Lordship said:

\footnotetext{
It is useless to ywure the law merchant or what Lord Manstield sald or did in his day. as what he did or satd has nu retevance whatsuever $t 0$ modem banking busness. What I muss look at is the facts ui the ase as explained by the witnosses who testivied and the current proctices of reputable bankers in the lield of whit other banks are doing under the heading of busuness pertaiang to banking.
}

O'Sullivan J. A.. on the other hand, while stating that he was substantially in agreement with Monnin J. A., delivered a judgment in which he took pains to point out that the two services being provided by the Toronto Dominion Bank were no more than a natural development of the use of computers by banks and the manipulation of information contained in those computers. The learned Judge pointed out that the bank was preparing financial statements of its customers for its own internal use and that there seemed no reason why the statements thus prepared should not be made available to the customers themselves for their own benefit. The thread that is common in both judgments, however, is that the activities comprised within the "business of banking" are different in different eras, and that it is probable that the scope of those activities will continue to change over time. The case is noteworthy for its rejection of case law from an earlier time as a guide to determining the. authorized scope of those activities today.

The decision in Central Computer Services has been limited in respect of the provision in Canada of data processing services by Section 174(2)(j) of the Bank Act, which limits banks to the provision of "bank related data processing services" as prescribed by regulation. The approach adopted by the Court to determining what is the business of banking remains, nonetheless, applicable in future cases.

Turning from these general considerations, the Bank Act contains certain restrictions on the powers of banks which are useful to keep in mind when preparing a loan agreement. One general point is that there is a lack of authority on Section 177 and its predecessors. In conisequence, it is necessary to look to the case law on Section 178 and draw a parallel between the two Sections. A Court which is called on to make decisions regarding the scope of Section 177 security may, of course, refuse to follow the principles laid down for Section 178 security. 
Dealing now with individual sections. section 193(2) of the Bank Act prevents a bank from holding more than ten percent of the shares of any company other than a bank service corporation and certain other corporations engaged in financial activities. Section 193(12) contains an exception, whereby, for a two year period, a bank may hold more than that percentage on the realization of security. However, this exception may be of little use to a bank which has taken security on less than 100 percent of the shares of a closely held company. Even if the bank can compel a transfer of the shares, the shares may in practical terms be unsaleable, so that the bank may be left without any remedy and may be unable to retain its security on the expiry of this two year limit. Section 193 provides that the bank may seek an exemption from the responsible Minister so as to extend the two year period. However, one wonders what the Minister's attitude may be if he receives numerous applications for exemptions. There does not appear to be any case law on this point.

A second question, also apparently unresolved, is the extent to which a bank can assign security created under the Bank Act either to another bank or to a non-bank. This question is most likely to arise on a refinancing where a third party wishes to assume a bank's secured position. Section 179(8) of the Bank Act specifically provides that a guarantor who has paid a bank has a right to be subrogated to the position of a bank in respect of security taken under Sections 177, 178 or 186; and Section 179(9) provides that security taken by a bank under Section 178(l)(f), ( $($ ), (h), (i) or (j) may be assigned. The implication. therefore, seems to be that Section 177 security cannot be assigned.

This implication appears to be confirmed by Re Victor Vamish Co. ${ }^{16}$ That case held that Section 178 security (then section 88 security) was not assignable, and that a guarantor, therefore, could not be subrogated to the rights of a bank which has been paid by the guarantor. Section 179(8) of the Bank Act, discussed above, effectively overrules the Victor Varnish case. However, it may still be argued that the rule in Victor Varnish remains applicable to such statutory forms of security as Section 177 security, which are not expressiy stated by the Bank Act to be assignable.

It appears from the judgment that there was no provision for registration of Bank Act security in Ontario at the time when Victor Varnish was decided, and that, notwithstanding the lack of registration, a bank took priority over duly registered chattel morgages which were granted after the Bank Act security. In these circumstances, the Chief Justice stated that:

\footnotetext{
I think that to construe the Act as if it provided for the asionmen of the sectrity to a third parry would open the door so mde to a fraudulent uas of the Act that I mua dealine to conares it as inpliedly authoriaine thas which in does not exprasely autborize or ss impliedly auboriaing that which. in my

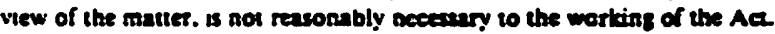

The rationale of the Victor Varnish case is, therefore, inapplicable in a jurisdiction such as Alberta where facilities for registration of an assignment under section 177 of the Bank Act are available, because, in such jurisdictions, the priority of the security depends upon priority in time of registration (Section 177(9) of the Bank Act and Section 140(4) of the Mines and Minerals 
Act). ${ }^{17}$ Nonetheless, the question of the assignability of Section 177 security is not free from doubt in view of the Victor Varnish decision. ${ }^{18}$

$A$ third question, also apparently unresolved, is whether a bank may hold in trust for a third party, security which it is not able to assign to that third party.

Going on to another point, the case of St. Louis Automobiles Ltee. v. Le Banque Narionale du Cancda ${ }^{19}$ indicates that where a bank is seeking to take advantage of a particular form of security that it is authorized to take under the Bank Act (in that case, Section 178 security), the bank will be acting beyond its powers if it attempts to take simultaneously a security which will give the bank rights that are additional to the rights specified in the Bank Act. The case concerned the validity of an agreement between the Banque Nationale and a car dealer which purported to give the Banque Nationale a power of seizure in circumstances not authorized by Section 178. The Court held that the agreement was illegal and void.

One difference between Sections 178 and 177 is relevant here, namely, that there is no provision in Section 178 corresponding to section 177(9). The latter provides that:

\footnotetext{
When making a loan or advance on the security provided for by this Section, a bank may take, on any property covered by this security. any further security in sees fir.
}

It is noteworthy that Section $177(9)$ states that the additional security may be taken "when making a loan or advance". It is, therefore, questionable whether the additional security could be taken after the loan or advance has been made. so that it is important for a bank which wishes to take any such additional security to ensure that the loan agreement specifies that the additional security is to be provided, or is agreed to be provided, at the time when the advance is made.

With respect to the capacity of the parties to a loan agreement (other than a bank), the doctrine of undue influence must be borne in mind where the borrowers, or the borrower and the guarantor, comprise related parties, such as husband and wife. See Lloyds Bank v. Bundy, 20 and such Canadian cases as Malicki v. Yancovich ${ }^{21}$ and The Royal Bank of Canada v. Hinds, 22 and contrast The Royal Bank of Canada v. Poisson. 23 The safest practice in such cases is to require that the related party be advised independently. This practice is recommended whether or not the Guarantees Acknowledgment Act ${ }^{24}$ must be complied with. For example, nothing in the Form of Acknowledgment under the Guarantees Acknowledgment Act requires that the Notary Public completing the acknowledgment be acting solely on behalf of the guarantor, or that the effect of the guarantee be explained separately and apart from any other person who may be involved in the transaction.

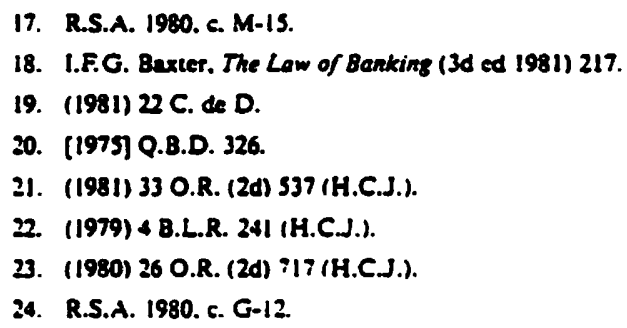


The issue of capacity may arise with respect to corporate borrowers incorporated under the Companies Act,25 the Business Corporations Act (Alberta) ("ABCA")26 and the Canada Business Corporations Act ("CBCA"). ${ }^{27}$

Companies Act companies are, of course, subject to the doctrine of ultra vires and the familiar decision of Mountview Charolais Ranch Lid. v. Haverland. 28 The doctrine of ultra vires has been substantially eliminated by sections 15 to 18 of the ABCA and the CBCA. The vestige that remains is contained in Section 42 of the two Acts, which contains the restrictions on trafficking and guarantees. However, Section 42(2)(a) of the two Acts provides an exception in favour of commercial lenders.

With respect to Companies Act companies, the judgment in Charterbridge Corporation Lid. v. Lloyds Bank ${ }^{29}$ suggests that it cannot be assumed that satisfaction of the Mountview' Charolais Ranch Lid tests is sufficient in all cases. Directors have a fiduciary duty to act only in the best interests of a company on whose Board they sit. A third party dealing with that company who relies knowingly on what amounts to a breach of trust by the directors will be precluded from recovering against that company on a promise made or on security given in circumstances amounting to a breach of trust. As a lender may be the best informed of all third parties about the affairs of a company, lenders may be vuinerable to the allegation that the lender must have known, by reason of its knowledge of the affairs of the company, that an act of the company's directors amounted to a breach of trust. As a protection for the lender, a certified copy of a resolution of the directors should be obtained in any transaction involving a company where there could be doubt about the benefit of the transaction to that company, whereby the directors state that they have considered the transaction from the point of view of the company alone, and have concluded that the transaction is in the best interests of that company.

Sections 18 of the $A B C A$ and $C B C A$ contain provisions designed to prevent a corporation raising defences based on lack of authority. It appears, however, that the provisions of the ABCA and CBCA may have made life more, not less, complex for lenders. In considering this point, the following Sections of the $A B C A$ and $C B C A$ are relevant:

Section IS II): A corporation tass the capaciny and, subject to this Act, the rights, powers and privileges of a matural person.

Section 18: A corporation or a guarantor of an obligation of the corporation may not assen againat a person dealing with the corporation of with any person who has acoutred rights from the corporztion thas

(d) a person held out by a corporation as a director. an officer or an apent of the corporation has not been duly apposnted or has no authonty so exercise the powess and perform the duties that are cusiomary in the business of the corporzuon or usad for such divectos. ofticer or apent.

(e) a document usued by any agent. director or ofticer of a corporation with serual or usual authority to wsue the document is not valid or not genuine.

3 R.S.A. 1980. C. C.20.

26. S.A. 1981. C. B-15.

:7. S.C. 1974-75-76. C. 33

28. (1974) 2 W: W.R. 289 (Alta. S.C.T.D.)

9 (1970) I Ch.D. 62 lpage 69 at C. and page 74 at E). 
exespt where the person has or ought to have by vrtue of his position with or etistionsnip to : sorporztion knowledge to the contrary.

Section $(17(1)$ : Every director and officer of a corporation in exeretsing his powers and tischarging nis durses shall

(a) zen honesty and in good faith with the view to the best interests of the corporation: Ind

(b) exercise the eare. diligence and skill that a reasonably prudent person would exercise in comparabie crcumanances.

The provisions quoted above are from the CBCA. The provisions of Sections 15 and $117(1)$ of the $A B C A$ are identical, and the provisions of Section 18 of the $A B C A$ are not materially different for present purposes.

It will be seen that the provisions of Sections 117 of the above Acts. when read with the exception to Sections 18 and the portion of the Charrerbridge case referred to above, make it arguable that it is more difficult under those tcts than under the Companies Act for a lender to rely on a resolution of the directors of the kind suggested above. If the circumstances are such that a reasonably prudent person would not believe that a transaction is in the best interests of the corporation (an objective test), and if the lender has actual knowledge of the circumstances, or by virtue of his relationship to the corporation ought to have knowledge of the circumstances, he may be unavoidably fixed with knowledge of a breach of trust on the part of the directors. If Charterbridge is followed on this point, the lender will be unable to rely to the detriment of the company on the acts of its directors. A similar result could be achieved in circumstances where a lender has knowledge of other breaches; e.g., of the corporate opportunity rules, or rules against trafficking.

\section{CHECK LIST}

A checklist for a commercial loan agreement is attached as Appendix A to this paper. Appendix A is based upon the list prepared by Michael Dennis which was published in the Meredith Memorial Lectures. ${ }^{30}$

\section{LOAN COMMITMENT}

The three types of loans commonly encountered are revolving lines of credit, term loans, and interim loans, being, respectively, loans which fluctuate subject to a fixed ceiling; loans which are paid down over time on a predetermined schedule and which do not increase once they have been reduced; and loans for an interim period only, for example, during a construction period, and which are not normally paid down at all until they are paid out from the proceeds of the permanent financing.

A lender and a borrower may have several of the above types of loans outstanding at one time, and different interest rates and items of security may be applicable to the different segments. The need for a loan agreement in such circumstances in order to identify the terms and security applicable to each segment is apparent. The standard banking forms cannot be made sufficiently flexible or precise to cope with the range of circumstances that can arise.

The term of the commitment of the lender is clearly a key part of a loan agreement for a borrower. The interaction between this commitment, the 
repayment provisions. and the provisions commonly found in loan agreements whereby discretion is granted to the lender as to the term of a commitment. can create severe difficulties of interpretation respecting the lender's remedies.

The borrower wants to know that the loan is available to him for a specified term at a certain interest rate with repayment over a specified period or at a specified time. The lender wants maximum flexibility in demanding payment if its likelihood of repayment decreases owing to the financial condition of the borrower or a decline in the value of its security.

These conflicting desires are usually addressed by the lender in the commitment letter, in which the lender will set out a complex set of terms of repayment over time, but, nonetheless, will stipulate that the loan is a "demand" loan. The paradox is also frequently reflected in the loan agreement where elaborate provisions for repayment over a stated period, and many pages of events of default setting out the circumstances in which the lender is to be entitled to demand repayment, will co-exist with a clause to the effect that the loan is a demand loan and may be demanded at any time in the lender's discretion, or to the effect that the lender is entitled to demand payment if, in its discretion, the lender determines that the loan has become insecure. As will be appreciated, this problem is particularly relevant today, when loans taken out by borrowers in more buoyant times are reviewed in the light of changed circumstances.

The Supreme Court of Canada in The Queen in Right of Alberte v. Arnold ${ }^{31}$ has held that a clause in a form of hypothecation of shares to the Provincial Treasurer entitling the lender to realize on his security in circumstances where it is the lender's view that to do so is "desirable for his protection", gives the lender the "legal power" to realize even without notice to the borrower. In considering the Arnold case, it is important to remember the facts as found by Martland J.. Arnold had written a letter to a firm of stockbrokers, in which he authorized that firm to forward to the Treasury Branch all proceeds of sale of certain of his shares held by the brokers, and the hypothecation of those shares in favour of the Treasury Branch oceurred after the letter to the stockbrokers had been written. The implication from the facts as found by the Court was that Amold specifically contemplated that his shares would be sold in order to keep his account at the Treasury Branch within agreed limits. Hence, this was not a case where security was given in the more usual type of arrangement. In these circumstances, Martland J. concluded that "the sales of the shares were not effected unlawfully, without the respondent's authority."

A different set of facts may give rise to a different result. Let us suppose that a loan agreement is in existence containing the contradictory provisions mentioned above, that the borrower has been paying the usual stand-by fees as consideration to the lender for keeping the loan available, and that the lender advances money and shortly thereafter decides that the value of its security is not as high as previously thought in view of a revision of the lender's criteria for determining the value of security (e.g. a downward revision in the lender's projection of future oil and gas prices, or of future demand for office space in the city of Calgary). There appears to be a very strong argument to be made by a borrower which is not otherwise in default under its loan agreement: (a) that a loan agreement must be construed so as to give it business efficacy and that a

31. (1970) is D.L.R. (3d) S7A (S.C.C.). 
court will effectively render meaningless the elaborate provisions for evears of default if it allows the lender to demand payment on the happening of an event which could reasonably have been foreseen at the time the loan agreement was prepared, but which was not included as an event of default: (b) that it is an implied fundamental term of the loan agreement, or, depending upon the wording of the agreement, a collateral contract, that payment will not be demanded uniess the circumstances fall outside the reasonably foreserabit range just mentioned; or (c) that (depending on the facts) the lender is estopped from exercising, or has waived, his right to demand payment unless there is an event of default.

Stuart H. Cobbett has suggested in the Meredith Memorial Lecrures 32 that if a facility is to be a demand facility, then no covenants or conditions should be contained in the loan agreement respecting the circumstances to be maintained in existence or the conditions to be met for continuation of the loan; rather. the lender must rely solely on his discretion to demand payment. It seems most unlikely to this writer that either lenders or borrowers would be willing to accept such an arrangement, and this unwillingness itself indicates that these "demand" clauses do not correspond to the reality of the agreement between the borrower and the lender. 33

There are no easy solutions to this problem. The writer's experience is that bankers are strongly attached to what they see as the ultimate remedy of demanding immediate payment. A lawyer acting for a bank should caution his client that the remedy may not be as unfettered in law as the bank would like to suppose. A lawyer acting for the borrower should fight hard to eliminate the "demand" provision, on the grounds that the lender is adequately covered by the events of default. If the bank will not agree to eliminate the remedy, $a$ second approach is to attempt to limit the demand feature to circumstances not within the contemplation of the parties at the time the loan is agreed upon.

\section{PREPAYMENTS}

Where the borrower has agreed to make repayment of principal over a specified period by specified instalments, there is no general right for the borrower to pay more than is owing at a particular time. The acceleration of repayment is, therefore, a privilege for which it is customary to pay, as in the case of the three-month interest penalty commonly required for prepayment of a residential mortgage. In the case of a commercial loan, the prepayment premium is frequently calculated as a percentage of the sum prepaid.

The exercise of a prepayment privilege will often be a consequence of the borrower obtaining a loan from another financial institution. This may be the unexpressed concern of a banker who insists on a prepayment premium, and it may, therefore, be possible to negotiate an arrangement that the prepayment premium will only apply in the event of refinancing with another institution, but not, for example, if prepayment is effected from the proceeds of an issue of equity. 


\section{FORM OF ADVANCES}

In addition to making a loan available by way of cash, a bank may make a loan available by means of bankers' acceptances or letters of credit.

\section{A. BANKERS' ACCEPTANCES}

A bankers' acceptance is a bill of exchange under the Bills of Exchange Act ${ }^{34}$ which takes the form of an order from the customer to the bank to pay a specified sum to the order of the customer either on demand or at the expiry of a specified number of days from the date of the acceptance. The "acceptance" is the signature of the bill by way of acceptance (i.e. guarantee of payment) by the bank. The practice is that the accepting bank in fact pays each bankers' acceptance when it falls due and charges the sum paid to its customer. The Canadian market for bankers' acceptances exists principally in Toronto and Montreal. A purchaser of a bankers' acceptance maturing at a future date naturally pays less than the face value of the bankers' acceptance which he purchases.

The cost to the bank's customers of using bankers' acceptances is, therefore, made up of the difference between the face value of each bankers' acceptance and the sum that he will receive for it in the market, plus the stamping fee which the bank charges to the customer for accepting each bankers' acceptance. Depending on the state of the market, these costs may amount to a greater or lesser interest charge than the same customer must pay to the bank on an ordinary floating rate loan. In making this computation, the customer must bear in mind that the notional "interest" charge on bankers' acceptances is borne by the customer immediately upon the negotiation of the bankers' acceptance (because the customer will receive less than the face value of the acceptance), whereas interest is normally paid in arrears.

A reason for using bankers' acceptances apart from interest rates is the access which bankers' acceptances give to a source of finance other than the chartered banks. Even in times of monetary restraint a bank may be able to accept a bill where it would be unable to lend a customer the face value of the bill.

When a bankers' acceptance falls due, the customer must reimburse the bank. This may be done either by drawing a further bankers' acceptance (known as a "rollover") or by drawing down an established loan facility.

\section{B. LETTERS OF CREDIT}

The term "letter of credit" covers a number of different types of instruments. The best known is a document which originated as a means to facilitate the import/export trade: a vendor/exporter is guaranteed payment upon satisfaction of certain conditions (e.g. delivery of goods in a specified condition to a named shipper, the goods being covered by specified insurance), while the purchaser/importer is guaranteed that the vendor will not receive payment until the conditions specified by him have been met. Another category of documents covered by the phrase "letter of credit" is, in essence, a bank's guarantee that payment of up to a specified amount due on or before a 
specified date to a specified person will be met by the bank. Such letters of credit are frequently no more formal than a letter written by the bank to the proposed payee.

A person who takes a letter of credit of this second category should be aware of three cases which indicate that it is not within the scope of the.authority of the manager of a branch of a bank to guarantee the debts of third parties. at least where the bank has no interest in the matter. These cases also state that it is ultra vires a bank to give such a guarantee. The three relevant cases are Michaud v. La Banque Provinciale du Canada. ${ }^{35}$ The Merchants Bank of Canado v. Stevens ${ }^{36}$ and MacIntosh v. The Bank of New Brunswick. ${ }^{37}$ It therefore appears to be essential for a recipient of such a letter of credit to ensure that the bank is interested in the transaction, as, for example, where the bank is receiving a fee for giving the letter of credit.

Letters of credit may be advantageous to both the payor and the pavee. From the point of view of the proposed payee, he need do no more than take the letter of credit and a post-dated cheque from the payor. So long as he has confidence in the bank's ability to pay, he need not concern himself with taking security. From the point of view of the payor, a letter of credit may avoid the giving of security, and it may be easier and cheaper to convince the payor's bank of the payor's ability to pay at a future date than to attempt to convince the payee.

\section{INTEREST RATES}

\section{A. PROVISIONS OF THE INTEREST ACT ${ }^{38}$}

The Interest Act poses a number of hurdles that the draftsman of a loan agreement must overcome.

\section{Section 3}

Section 3 states, in part, that:

whenever any intereat is payable by the agreement of parties or by law. and no rate is rixed by such
agreemeat of by law, the rate of interest shall be five percent per annum.

A question which has vexed practitioners is whether a floating rate of interest can be said to be "fixed by such agreement".

The case of V.K. Mason Construction Lid. v. Courtot Investments Lid.. ${ }^{39}$ was decided in relation to a Libor borrowing, where the rate of interest under a loan was to be determined by reference to Libor. The Court held that although there was no single rate which can be identified as the London Interbank Eurodollar offer rate, because each bank fixes its own rate, the agreement was sufficiently precise to oust the provisions of Section 3 of the Interest Act.

\footnotetext{
35. [1961] Que. S.C. 207 (Que. S.C.).

36. (1919) 49 D.L.R. 528 (Man. C.A.).

37. (1913) 42 N.B.R. (152 (S.C.).

38. R.S.C. 1970 . c. 1-18.

39. (1980) 10 B.L.R. 78 (B.C. S.C.).
} 
By extension, an agreement to pay interest by reference to the prime rate of a named bank should be held to be sufficiently clear to oust the five percent rule under Section 3. An examination of the V. K. Mason case shows that the Court was fairly lenient to the lender with respect to the interpretation of Section 3. One may speculate that this was because the Court found against the lender on a different issue, namely Section 4 of the Interest Act.

It is the nature of the Libor market that there are several variables which go into determining the Libor rate for a particular loan, and the rate may vary by the hour on any particular day. Other factors which influence the rate inciude such matters as the currency in which a loan is to be made, the length of the period for which it is to be available, the size of the loan and the market's assessment of the financial strength of the borrowing bank. In some cases, the borrowing bank may be part of a group which borrows together. It is, therefore, easy to see that the interpretation of Section 3 that was approved by the Court in the V. K. Mason case could just as easily have been found to be deficient in several particulars, all of which will normally be taken into account in the provisions relating to Libor that are contained in a loan agreement.

A second point with respect to Libor loans is that it is common to give the borrower a number of choices with respect to a Libor loan. In the event of a default, the borrower may be unable or unwilling to make such elections. The loan aÇgreement must, therefore, give specifications for deemed elections by the borrower if there is a default, or it may be preferable to deem that on default the borrower elects to convert Libor loans to a segment of the loan commitment to which Libor does not apply.

A further refinement of the provisions of the loan agreement dealing with Libor is to specify that the rate will be determined not by the rate offered by the lender, but by the rate offered to the lender. This has the advantage of removing some of the lender's discretion in fixing interest rates, which discretion is perceived as objectionable both in relation to Libor and to prime rate loans; such a provision may also increase uncertainty, as the lender at any given moment may receive different quotes as to initerest rates on an identical offer to lend made by that lender to different participants in the Libor market.

\section{Section 4}

This Section does not apply to mortgages on real estate. It does apply to every other written or printed contract and provides that whenever interest is:

\footnotetext{
made payable at a sate or percentage per day, week, woath. or at any rate or percentage for any period less than a year. no interest exceeding the rate or percentage of five (5\%) percens per annum shall be... . recoverable. unless the contrect contains as express autemeas of the yearly rate of percantage of imterea to which such otber rate or peremenge is equivalem.
}

Questions which arise immediately in the case of an oil and gas company is whether the form of security taken by a bank is a "mortgage", and whether the interest held under a freehold or Crown lease of hydrocarbons is "real estate".

As was noted in the St. Louis Automobiles case, 40 it appears that the powers of a bank under Section 178 security are exhaustively enumerated in the Bank Act. In the absence of authority, one must assume that a similas principle 
would be held to apply to Section 177 security. It appears, therefore, that an assignment under Section 177 cannot be taken as conferring on a bank at least one of the powers characteristic of a mortgagee, namely a right of foreclosure. Section $177(3)$ states that a bank has the right to "take possession of, seize, care for, maintain, use, operate ... sell, the property covered by the security or part thereof as it sees fit". No mention is made of a right of foreclosure. This is notwithstanding that the form of the security in Schedule $I$ to the Bank Act is in the form of an outright assignment, the original form of a legal mortgage. If one looks for assistance to the very similar provisions of Section 178(3) and Schedule $G$ of the Bank Act, it has been held in Canadian Imperial Bank of Commerce v. Heppner ${ }^{41}$ and in Guimond v. Fidelity-Phenix Fire Insurance Co. ${ }^{42}$ that an assignment under Section 178 of the Bank Act is not a chattel mortgage. It appears, therefore, that a Section 177 assignment should be held not to constitute a land mortgage.

As to the question of whether the interest held by a grantee of a freehold or Crown lease is "real estate", the answer appears to be that it is. ${ }^{43}$

As is well known, however, the courts have yet to make any rulings regarding Section 177 of the Bank Act. The only safe course of conduct for a person drawing a loan agreement. therefore, is to regard both Section 4 and Section 6 of the Interest Act as applicable to Section 177 security.

It is normal in the case of a Libor loan, and also in the case of many U.S. dollar loans, for interest to be calculated on the basis of a 360 day year. It is obvious, and it was so held in the $V$. $K$. Mason case, 4 that 360 days is not a year. In order to get around this problem, a provision is normally inserted in cases where a 360 day year is involved to the effect that the quoted "annual" rate of interest is equivalent to the said rate multiplied by the number of days in the year and divided by 360 .

One similar point is that some banks in fact charge interest on the basis of a year of 365 days, notwithstanding that the year is actually a leap year and so contains 366 days. In view of the catastrophic consequences for a lender of failure to comply with Section 4, a provision similar to the one just mentioned can be inserted in respect of interest rates that are calculated on the basis of a 365 day year, to the effect that they are equivalent in a leap year to the rate quoted multiplied by 366 and divided by 365 .

A further interpretation which has been placed on Section 4 is that it requires a statement of the "effective" annual interest rate, which depends on the frequency with which interest is calculated and paid, and on a principle known as the "reinvestment principle". This latter relates to the benefit which a lender that is paid monthly can derive from reinvesting the monthly payment, a benefit obviously denied to a lender which is paid less frequently. On this theory, 10 percent per annum paid monthly is an effective rate greater than 10 percent per annum paid yearly.

41. (1965) SI D.L.R. (2d) 3SA (Sask. Q.B.).

42. (1912) 9 D.L.R. 463 (S.C.C.).

43. Momrreal Lighr. Heat and Power Consolidosed v. The City of Westmoune [1926] S.C.R. S1S; Berkhenser v. Berkeiser and Glouster I19S7) 7 D.L.R. (2d) 721 (S.C.C.): Arkenses Fuel and Minerals Lid v. Dome Petroleum Led (1965) SA D.L.R. (2d) S741 Alts. S.C. App. Div.):Re Monired Trust Compony's Applicetion (Clevetend Euere) (1963) \&1 W. W.R. 193 (Sask. Q.8.).

4. Supre n. 39. 
The Supreme Court of Canada addressed this issue in Re Merropolitan Trust Co. Lid. and Morenish Land Developments Lid. 45 In that case, the Supreme Court found that there was no rule of law which required an application of the reinvestment principle, and held that whether or not the principle is to be applied must be inferred from the terms of the contract. The Court clearly felt that to apply the reinvestment principle would be to do violence to the terms of the contract between the parties:

\begin{abstract}
From a prectical viewpoint. the assumption that the lendet will reinvest interes payments when received at the rate specified in the monpage is tantamount to esublishiag. without express apresment

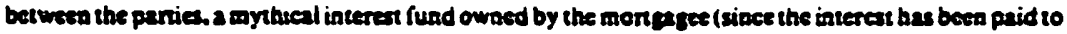
him under the contreet by the mongagor) but whose mythieal carriags are credited to the mortgagor

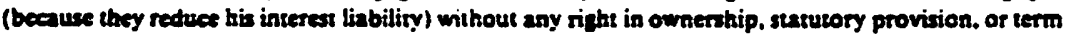
of contrea to support the practice. Furthermore. the ausmed reinvestment proctedr are aot subjected to eny charee or credit for the cost of rennvestmeat incurred by the morgagee, his bed debes in the

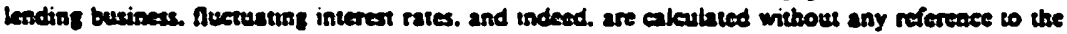
eapacity of ability of the mortpagee in fact to reinvest the proceds.
\end{abstract}

The Court was thus able to distinguish an earlier Ontario case, Re Fobesco Ltd. and Abrams et al, ${ }^{46}$ which held that the reinvestment principle was applicable on the facts.

It also appears from the Metropoliten Trust case that the Supreme Court is not anxious to give an unduly technical interpretation to the Interest Act where the result of so doing is to undo a contract freely made between sophisticated parties.

\title{
3. Section 6
}

This Section is probably the most familiar to all of us and deals exclusively with mortgages of real estate where the loan is "by the mortgage" made payable on a sinking fund plan.

This paper will not comment further on this provision, because most loan agreements in fact provide separately for payment of interest and principal. Also, it appears from Asconi Building Corporation and Vermette v. Vociseno. 47 following London Loan \& Savings Co. of Canada v. Meagher, 48 that Section 6 is inapplicable where the primary obligation is not contained in a document which is itself a mortgage, notwithstanding that there is also a collateral mortgage.

\section{Section 8}

This Section applies only to loans secured by mortgages on real estate, but unlike Section 6, Section 8 applies wherever interest provisions are contained. Section 8 prohibits the charging of interest on payments in arrears at a rate higher than the rate charged on payments not in arrears. Subsection $8(2)$ expressly states that nothing in subsection $8(1)$ is to be taken as prohibiting the charging of-interest on sums in arrears at a rate not greater than the rate
45. (1981) 118 D.L.R. (3d) 385 (S.C.C.).
46. (1976) 71 D.L.R. (3d) 43 (Ont. H.C.J.).
47. [1947] S.C.R. 358.
48. [1930] S.C.R. 378. 
applicable on sums not in arrears. The limitation of Section 8 to loans secured by mortgages on real estate should be remembered, as some lenders appear to believe that Section 8 applies to all loans, however they are secured.

One problem which has been raised is whether a floating rate of interest may be prohibited by Section 8 in certain circumstances. Suppose, for example. that while a loan is not in default the prime rate does not exceed fifteen percent, but that after the loan goes into default the prime rate climbs to seventeen percent. In considering this problem, the wording of Section 8 should be borne in mind:

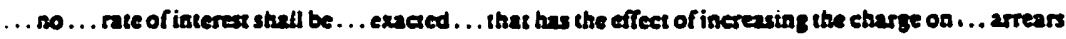
beyond the rate... payable on prineipal money not in arrear.

The words "has the effect of" are noteworthy.

At least two solutions are suggested. A clause can be inserted to the effect that if the prime rate in force after default exceeds the highest figure at which it stood during the time that the loan was current, then prime shall be deemed to be limited to the latter rate for the purpose of calculating interest on arrears. Alternatively, a fluctuating rate of interest can be expressed to be payable "to the extent permissible by law".

Dealing next with cases where interest is expressly made payable at a higher rate after than before default, there is a conflict in the case law on Section 8 of the Interest Act. The courts of first instance in British Columbia and Ontario have decided one way, and the Court of Appeal in Quebec the other way, on very similar facts. In all three cases, no interest was payable before default, and interest at a specified rate was payable after default.

In Pemberion Realty Corp Lid v. Carter, ${ }^{49}$ the Court followed the reasoning of an earlier line of cases from Ontario and held that no interest was payable on arrears. In Developpements Esprit Limited v. Brisson, 50 the Court held that it would be specious to argue that a specified rate is an increase over a rate of zero percent and that the purpose of the Interest Act (namely, the proscription of devices that prevent a debtor from understanding the effect of his obligations) was served by the express statemeat of the rate applicable on arrears. In addition, the Court stated that the principle of freedom of contract set out in Section 2 of the Interest Act should be the guide to the interpretation of that Act, and that provisions which derogate from that principle should be construed restrictively. The Pemberton case was not referred to.

The contrary position was taken by Henry J. in Re Weirdale Investments Ltd. and Canadian Imperial Bank of Commerce. ${ }^{51}$ That case held invalid, as contravening Section 8, a commonly-used provision whereby interest is charged at the same fixed rate both before and after default, but which stipulates that interest at a lesser rate 52 will be accepted by the lender if prompt payment is made. The Court noted that the provision in question was of a type that. had been expressly sanctioned by the House of Lords and approved by leading textwriters, but concluded that the Interest Act had changed the common law rule which gave relief against penalties by directing that such provisions must be tested by their effect, not their form. The Developpements Esprit case was not referred to in Re Weirdale.

49. (1975) 58 D.L.R. (3d) 478 (B.C. S.C.).

SO. (1950) C.A. 293.

51. (1981) 121 D.L.R. (s0 (Ont. H.C.J.).

52. Supro n. S1 a 152 
IVOL. XXII. NO. 1

In view of this conflict, it seems clear that the correct interpretation of the effect of Section 8 is ripe for decision by the Supreme Court of Canada. If one accepts the policy which is expressed in Section 8, then, it is apparent that the decision in $R e$ Weirdale is to be preferred in most cases to the decision in Developpements Esprit. It is arguable, however, that an exception should be made for cases such as Developpements Esprit where there is no interest prior to default; it seems unreasonable that the law should set a trap for someone who is prepared to let a borrower have free use of his money (e.g. a shareholder lending to a private company) and who only requires payment of interest if default is made when payment becomes due.

\section{Section 13}

Section 13 of the Interest Act states that: "Every judgment debt shall bear interest at the rate of five percent per annum until it is satisfied." By Section 15, "any costs, charges or expenses made payable by or under any judgment" are included in a "judgment debt".

In Bank of Nova Scotia v. U.P.C. Holdings Ltd et al.53 it was held that a promissory note in the usual form requiring payment of interest at a specified rate "as well after as before demand or payment" did not oust the statutory rate after judgment. The Court gave a strict interpretation to the words contained in the promissory note and relied for authority on the 1884 decision of the Supreme Court of Canada in St. John v. Rykert, 34 where it was held that "precise and unambiguous language" is necessary where the parties wish to stipulate for a larger amount of interest than the "usual and legal rate". The difficulty with the decision, of course, is that a rate of five percent is hardly usual today. In consequence of the U.P. C. Holdings case, it is necessary in a loan agreement to stipulate that the agreed rate of interest is applicable as well after as before "demand or judgment". It should also be noted that the U.P. C. Holdings case did not decide that parties can contract out of the provisions of Section 13, because defence counsel conceded the point. However, the Court approved the concession in obiter dicta.

\section{B. PRIME RATE}

It has been customary for some time to define "prime rate" as the rate of interest charged from time to time by the lender on substantial loans to its most credit-worthy customers. The assumption was that this rate was the rate which is posted in the local branches of the various chartered banks, and which, of course, can vary on any given day from bank to bank. It transpires that the biggest and best customers of some banks have been able to get loans at less than the published prime rate. The effect of this definition may, therefore, be to lower the rate of interest chargeabie on a loan to less than the rate expected by the lender. This point was central to the recent decision in Bank of Montreal v. Dezcam Industries Lid. ${ }^{55}$ in which a promissory note was held invalid because

\footnotetext{
53. (1979) II Ale. L.R. (2d) 331 (Q.B.). The Brizish Columbu Supreme Coun has confirmed that parties may contret for a rate different from that suputated by Sectson 13: Benk of British Columbie v. Bellence and Betes [1983] 2 W. W. R. 566 (B.C. S.C.).

SA. (1884) 10 S.C.R. 278.

5S. [1983] s w.W.R. 83 (B.C. C.A.).
} 
the amount promised was not a "sum certain". The rejected instrument referred to "the rate of interest charged by the Bank of Montreal to its most credit-worthy customers from time to time", which the bank manager equated with the prime rate in his evidence, but which the Court found uncertain in that the evidence further exhibited that some borrowers received loans at below prime.

An alternative clause that has been gaining currency provides that "prime rate" means the rate announced as being the prime rate from time to time by the lender. Stuart Cobbett ${ }^{58}$ queries whether this formulation can meet the test of Section 3 of the Interest Act, on the grounds that, at least in theory, the formulation leaves the determination of prime rate entirely to the discretion of the bank, which is not required by the terms of the formulation to have any regard to market forces. (Contrast the Mason case, ${ }^{57}$ where the Court found that even though Libor was not a fixed market rate it was at least determined to some degree by the market forces at work in the London Interbank market.) $\mathrm{A}$ formulation which would overcome this problem would be to define the prime rate as the rate announced by the bank as being its prime rate and used by the bank generally for determining what interest will be charged to its customers on floating interest rate loans. Market forces are allowed in by this formulation because a bank could not afford to be non-competitive in the rate generally used by it as a reference for determining interest charges.

\section{$X$. EVIDENCE OF INDEBTEDNESS}

Almost invariably, a loan agreement calls for the amount advanced to be evidenced by a promissory note drawn by the borrower in favour of the lender. Other evidence of indebtedness may include a debenture.

One may question why promissory notes are so commonly taken. From the point of view of the lender, a promissory note has the advantage that a person suing on a note need not show consideration, and that a promissory note, being a form of bill of exchange, is a negotiable instrument. In practice, both of these advantages are more illusory than real. The writer's understanding is that it is almost unheard of for a bank to negotiate its customers' promissory notes where that promissory note is held as collateral security for a loan, and one may well imagine that there are not that many borrowers whose notes are readily marketable. The other advantage, namely, not having to prove consideration, is only a rebuttable presumption as between the maker and original payee of a promissory note. The maker would not be prevented as against the original payee from denying the existence of consideration if the circumstances were appropriate; nor, indeed, is the maker prevented from raising such equities as may exist between the parties when the maker is dealing with the original payee. It is only a holder in due course who takes free of equities.

From the point of view of both borrower and lender, it is a nuisance to issue promissory notes every time a drawdown is made in the case of a loan where drawdown may be made in several instalments. From the point of view of the borrower, it is often difficult to keep track of how many promissory notes have 
been issued to the lender, and, of course, a prudent borrower will wish to get back all his notes once the loan has been fully repaid. In the case of a revolving loan, it is easy to imagine the jumble of paper which can be created if new notes are issued and old notes are cancelled as the amount of the loan fluctuates.

In this respect, banking practice in North America is different from the practice in Britain, where bankers may never see a promissory note from one year to the next.

One solution has been to create the so called "grid note". This is no more than an ordinary promissory note with a printed grid on the reverse. The grid has columns for the date, sums payable to the holder, sums received by the holder, and balance owing. As new sums are drawn down under a facility or sums are repaid, an appropriate dated entry is made on the reverse of the note and the balance following the adjustment is also shown. The promise to pay on the face of the grid note is a promise to pay whatever balance is shown as outstanding on the grid, and all changes on the grid will, of course, be initialled by the parties.

An alternative to this rather antiquated bookkeeping system is to rely on the loan agreement itself as evidence of the borrower's agreement to pay, and on the lender's records of the account maintained by the borrower with the lender as evidence of what monies have been advanced.

So long as banks persist in taking promissory notes, it is incumbent on their lawyers to ensure that those notes meet the tests of the Bills of Exchange Act. A number of recent decisions are worthy of attention. In MacLeod Savings and Credit Union Lid. v. Perrett. ${ }^{58}$ the Supreme Court of Canada held invalid a promissory note that bore interest from the date of the first advance, on the grounds that the date of advance could not be determined from the face of the note. The Court also released the individual endorsers from liability as there had been no compliance with the Guarantees Acknowledgment Act. Judicial applications of the MecLeod case to notes containing prime rate (or similar) references are conflicting, ranging from rejection of the notes in Bank of Montreal v. A \& M Investments Lid 59 (which referred to the Bank of Montreal's "Small Business Rate") and Bank of Montreal v. Burchert, ${ }^{60}$ to acceptance of the notes in Royal Bank of Canade v. Reed ${ }^{B 1}$ and Royal Bank of Canade v. Temvest Inc.62 As noted previously, it has recently been beld by the British Columbia Court of Appeal in Bank of Montreal v. Dezcam Industries Lid. ${ }^{63}$ that a reference to "the rate of interest charged by the Bank of Montreal to its most credit-worthy customers from time to time" did not disclose a "sum certain" in similar circumstances. It is clear that further application of the $A \& M$ Investments and Burchen cases would result in the invalidity of an untold number of promissory notes, and that care must be exercised in defining prime rates, or similar rates, so as to avoid the result in Dezcam. Perhaps the courts will decide that the "prime rate", when defined as a rate published or stated by
58. (1981) 118 D.L.R. (3d) 193 (S.C.C.).
9. (1982) 136 D.L.R. (3d) 181 (Sesk. Q.B.) (under appeal).
60. (1983) 18 A.C.W.S. (2d) 459 (Ont. S.C.).
61. [1983] 2 W. W.R.. 419 (B.C. S.C.).
62. (1982) is A.C.W.S. (2d) 362 (Ont. Dist. Ct.).
63. Supra a. 55 . 
a given chartered bank as its prime rate from time to time, is sufficiently notorious that commercial expediency will prevail so as to uphold such instruments as promissory notes.

Grounds for hope may be found in the following passage in the MacLeod Savings case, which shows that there is still room for the courts to find promissory notes bearing interest at prime to be valid bills of exchange:

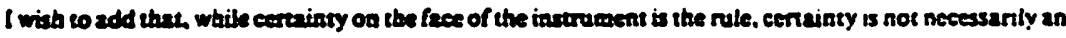

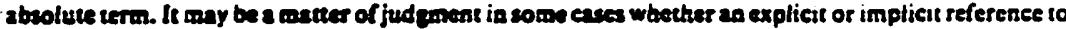

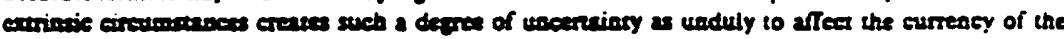
inetrumear and ates its nature.
}

Beetz J. has thus left an opening through which the law may be adjusted to current commercial practice.

By way of footnote to the $A \& M$ Investments case, ${ }^{84}$ neither the debtor nor the guarantor in that case was able to escape paying the bank. The Court was able to find ample evidence of the debt, including the invalid promissory note.

Even where a note is a valid promissory note, a lender to which such a note is negotiated may still be prevented from having the status of a holder in due course if the lender enters into a collateral agreement that restricts its rights as a holder in due course. A recent case on point is Williams \& Glyn's Bank Limited v. Belkin Packaging Limized (1983) 47 N.R. 241, a decision of the Supreme Court of Canada. The Bank in that case was the endorsee of certain promissory notes issued by Belkin Packaging. The notes were issued in connection with the purchase of machinery by Belkin from a British exporter. The process of negotiating the sale contract had been complex and the Bank had been closely involved in the process. The Bank gave an undertaking, inter alia, only to sell the notes to a specified party and to exchange the notes for new notes.

The Court beld that because of the inconsistency between the Bank's undertaking and the rights of a holder in due course, the Bank had lost its status as a holder in due course. The case shows the danger that faces a Bank which wishes to maintain the advantages of holding a promissory note, and yet make the compromises which may be necessary in order to permit a business transaction to proceed.

The case also raises, but does not decide, some interesting questions as to the rights of a holder for value of a promissory note.

\section{FOREIGN CURRENCY OPTIONS AND LIBOR}

Where a loan is to be denominated in a foreign currency but the loan agreement is to be governed by the laws of Alberta or other Canadian provinces, the same considerations as set out above apply in respect of the Interest Act.

In the case of U.S. currency loans (the foreign currency loan most commonly met with), reference to prime rate is normally replaced by reference to "U.S. base rate", but the considerations relating to a fluctuating "prime plus" loan remain otherwise unchanged.

As an alternative in the case of major world currencies, including the U.S.

64. Supre n. 59. 
dollar, the Japanese yen, the German mark, the Swiss franc and the Canadian dollar (although, at the request of the Federal Government, Canadian banks do not make Canadian Libor loans available to Canadian borrowers), loans may be obtained through the Eurocurrency Markets centred in London and Luxemborg. The primary reason for a borrower that wishes to take out a foreign currency loan to take a Eurocurrency loan is the difference which exists from time to time between the rate which a bank will charge for a direct loan in that currency and the Libor rate for the same currency. In addition. a Libor rate is fixed for the term of the Libor contract, which may vary from thirty days to five years, whereas "U.S. base rate" is a floating rate.

Generally speaking, a borrower will not wish, nor be permitted by its banker, to incur a foreign currency obligation unless the borrower has a source of income in that foreign currency; otherwise a borrower is taking a risk on exchange rates between the currency in which it has income and the currency in which it must repay the bank. It is possible, however, by the use of the forward currency market, to eliminate this exchange risk. In this way, a borrower that lacks the necessary source of foreign income can get the advantage of the fixed interest rates which are offered by the Libor market.

A loan agreement providing for Libor borrowings normally contains several more or less standard clauses relating to: the selection of a Libor interest period; the indemnification of the lender in the event of early termination of a Libor contract; a provison whereby the lender is given discretion to convert a Libor borrowing into another segment of the loan if the making or continuing of a Libor loan becomes unworkable or if the lender cannot obtain deposits of the required amount on the Libor market; and an agreement to pay the lender "additional compensation" if, for reasons outside the control of the lender, the lender's income from the making of a Libor loan is reduced.

To the writer's knowledge, the enforceability of such provisions has not been tested in Canada. Grave doubts are raised by the provisions of Sections 4,6 and 8 of the Interest Act, discussed above. Few interest rates can be less "fixed" than a Libor rate, and the Libor provisions can clearly make the rate of interest payable on arrears exceed the rate payable on principal money not in arrears. Such grounds as exist for optimism on the part of a bank in respect of Libor provisions are to be found in the V.K. Mason case, ${ }^{05}$ and in the Developpements Espirit case ${ }^{86}$ with its reference to the desirability of freedom of contract. It is to be hoped that the courts will not apply a strict construction of a consumer protection statute such as the Interest Act to the large commercial loans which are the subject of loan agreements.

\section{CONVERSIONS}

An agreement for loans to be available in several currencies usually provides for conversions between the various currencies.

One point always to bear in mind is the mechanics of making conversions. It is tempting to think of a conversion as a simple conversion of a sum denominated in one currency into a sum denominated in a different currency. On closer analysis, what happens when a loan is converted is that the required

65. Supre n. 39.

6. Supro a. so. 
sum in the new currency is advanced by the lender and is then used on the same day to pay off the existing liability in the currency from which the "loan" is being converted.

At least two consequences follow from the process. In the first place. the applicable exchange rate is the rate of exchange for the purchase of the old currency with the new currency, not vice versa as might be expected. Secondly. it is arguable that the making of a conversion amounts to the making of a new loan; that is, the making of the advance in the new currency for the purpose of paying off the existing advance in the old currency. Lenders, therefore. are concerned that they should not be taken as waiving any event of default which may exist at the time a conversion is made, and require that it be a condition for the making of a conversion that no eveat of default exist and that the representations and warranties be true at the time of the making of the conversion. This requirement will necessitate some drafting to take account of such inevitable changes in representations and warranties as will result from the passage of time (e.g.: provisions to ensure that references to financial statements are kept current).

A point on which counsel must also be clear is whether repayment of a loan denominated in several currencies is to be made by reference to those foreign currencies, or whether it is to be made by reference to Canadian dollars. This will make a difference to the repayment provisions. In the first case, the bank requires repayment of a certain number of units of one or more specified foreign currencies (as well, perhaps, as a set number of Canadian dollars); in the second case, the bank requires repayment of a certain number of Canadian dollars (although the bank may be willing to accept foreign currencies at the current rate of exchange against the Canadian dollar). In the first case, known amounts of various currencies are to be repaid over a specified period, so that - each instalment payment can be of a specified amount of each of the various currencies. In the second case, the measuring device is solely Canadian dollars and all repayments will be keyed to that currency.

A third alternative which leaves the borrower the maximum flexibility is for the borrower to repay a fraction of each of the loan segments which may be outstanding on each instalment date, of which the denominator will be the number of remaining instalment payments including the current instalment payment (e.go: if there are four remaining instalment payment dates, the borrower pays one quarter, one third, one half and then all of such amount as may be outstanding on the instalment date in each of the various segments). The advantage of this formula is that it leaves the borrower free to convert between currencies without regard to required repayments.

A problem which arises where the maximum amount of the loan is specifed (as is usually the case) is that currency fluctuations may, on a daily basis and without any intervention by the borrower, cause the amount of the loan, when converted to Canadian dollars, to be more or less than the maximum. The borrower will wish to ensure that the loan agreement provides for this eventuality and, in some cases, the lender will require that the botrower make a payment to the lender if a currency fluctuation causes the loan maximum to be exceeded for more than a certain period. The lender is, of course, concerned that the borrower's ability to repay may be prejudiced if currency fluctuations go against it over the period of the loan. The borrower may elect, or may be required by the lender, to protect itself against future fluctuations in currency 
rates by the purchase of the requisite amount of foreign currency in the forward currency market.

\section{DRAWDOWNS AND LEGAL OPINIONS}

A loan agreement will normally contain elaborate conditions to be satisfied before drawdowns can occur. These conditions may include: (a) delivery of certificates as to fulfillment of conditions-and truth of representations and warranties; (b) completion of security documents; (c) delivery of legal opinions; and (d) such other documents as the lender may reasonably require.

The principal cause of difficulty in meeting drawdown requirements from the lawyer's point of view is likely to be the provision of requisite legal opinions. The single best rule that can be formulated on this subject is that no lawyer should require another lawyer to give an opinion which the first lawyer could not give himself in the circumstances.

The opinion most frequently asked for, and one of the most ambiguous, is that the documents are "enforceable in accordance with their terms". The usual qualifications should include qualifications as to: (a) bankruptcy and laws affecting the rights of creditors generally; (b) the diseretion of the courts in granting any equitable remedy; (c) limitations imposed by the Foreign Investment Review Act57 on the right of a secured lender to dispose of his security on a realization; (d) the rights of federal and provincial governments to preferences in respect of taxes due; $(e)$ the rights of federal and provincial governments and also of third parties (see, for example, S.124(1) of the Alberta Insurance Act, 88 and those federal and provincial statutes that deem that recipients of funds hold them in trust for the government) under trusts imposed by statutes. Additional qualifications which may be negotiated relate to inherent contradictions or ambiguities and collateral contracts, the existence of which is not evident from the terms of the documents.

Where the security taken includes "securities" within the meaning of the Alberta Securities Act, ${ }^{\text {o9 }}$ counsel must be aware of the provisions of Section 112 of that Act and of similar provisions of the Securities Act of other provinces. A lender that realizes on its security must, unless the borrower has been a "reporting issuer" for at least 12 months and is not in defoult under the Act or regulations, either ensure that the sale comes within one of the exemptions set out in Section 107(1), or seek to obtain a specific exemption under Section 116. The principal exemption which may be available under Section 107 is the $\$ 97,000$ exemption under Section $107(1)$ (d); moreover, there is a current proposal to increase this limit substantially.

A further potential problem for counsel for a borrower who is required to give an opinion that a loan agreement is "enforceable in accordance with its terms" is that Counsel may find himself in a conflict of interest if he is later called upon by his client to challenge those terms. Counsel for the borrower should, therefore, qualify his opinion with a statement to the effect that he reserves the right to challenge the terms of the agreement at the instance of his client, and for the comfort of the lender be can add (if such is the case) that he

\footnotetext{
67. S.C. 1973-74. C 46.

68. R.S.A. 1980. C. I-S.

69. S.A. 1981. C. S.6.I.
} 
has no present knowledge of any intention on the part of the borrower to challenge the terms of the agreement. If, as is often the case, counsel for the lender refuses to change terms of a document on the grounds that they are "standard", it may be useful for counsel for the borrower to so state in his opinion.

The reader is referred to the article "Legal Opinions in Business Transactions - An Attempt to Bring Some Order out of Chaos" by James J. Fuld ${ }^{70}$ for a detailed discussion of the problems associated with rendering legal opinions.

\section{EVENTS OF DEFAULT}

The primary event of default is, of course, non-payment of principal or interest on the due date.

A controversy surrounding events of default relates to the so-called "cross default" clause. This clause stipulates that a default under an agreement between a borrower and any other lender shall aiso constitute an event of default under the present loan agreement. For the protection of the borrower. qualifications to this clause can include provisions that the other lender must have taken steps to accelerate payment of monies owing to him, or that a waiver by the other lender will be effective for the purposes of the present agreement.

An important clause from the point of view of the lender is a provision that all rights and remedies of the lender under the agreement are cumulative. and that the lender may pick and choose his remedies at his discretion. Such a clause may not be effective in all respects (e.g.: the lender may still be required to realize on his mortgage security before proceeding under a guarantee), but the attempt should be made to give the lender as much flexibility as possible. The writer's experience is that once the borrower is in default, the lender needs as much flexibility as possible to take the steps necessary to secure his position, because his position is often less secure than was thought likely when the loan was first made.

\section{JUDGMENT CURRENCY}

Encouraged by Lord Denning of the Court of Appeal, the English House of Lords revolutionized the established law by holding, in Miliangos v. George Frank (Texriles) Lıd. ${ }^{71}$ and The Despina $R$. v. The Folias 72 that a judgment on an agreement governed by foreign law may be given in England in a currency other than the pound sterling. The previous rule had always been that an English court would only give judgment in sterling, and that the applicable rate of exchange between foreign currency and sterling was the rate of exchange in force at the time of breach. The Miliangos case also changed this rule, so that the applicable rate of exchange is the rate of exchange at the time of payment under a judgment.

The law in Canada, as laid down by the Supreme Court of Canada, follows the pre-Miliangos English law. The present Canadian position, however, is confused. A complication is caused in Canada by Section 11 of the Currency

70. (1973) The Bustess Lonyer (April) as 915.

71. [1975] 3 All E.R. 801 (H.L).

72. [1979] I Lloyd's Rep. 1 (H.L.). 
and Exchange Act, ${ }^{73}$ which states that "any statement as to money or money value in any indictment or legal proceeding shall be stated in the currency of Canada". There is no comparable statute in England.

In Basavia Times Publishing Co. v. Davis. 74 Counsel for both parties were in agreement that Section 11 prevents a Canadian court from rendering judgment in a foreign currency, and judgment was given on this basis. The Court did, however, follow the reasoning of Miliangos rather than previous Canadian authority, and allowed the use of the rate of exchange at the date of judgment (not the date of payment; the Learned Judge assumed that he was precluded from rendering a judgment in a foreign currency and that, therefore, he could not follow Miliangos all the way). The Batavia rule seems to have become established in Ontario. ${ }^{75}$

In Am-Pac Forest Products Inc. v. Phoenix Doors Lid, 78 where the contract was governed by the laws of British Columbia, the British Columbia Supreme Court refused to follow the Batavia example and held itself bound by the previous Supreme Cour of Canada authority, namely, The Custodian v. Blucher, 77 to apply the exchange rate in effect on the date of breach. In Alberta, the courts are now rendering judgment on the basis of the rate of exchange at the time of judgment. 78

Thus, Canadian law on this point is in flux and the best that a draftsman can do is to attempt to nudge the courts in the right direction by expressly stipulating for the rate of exchange on the date of judgment or the date of payment under the judgment. By way of refinement, it is common to include a clause in such an agreement specifying the rate of exchange which will be employed; for example: the spot rate on the New York Foreign Exchange Market two days prior to the date of judgment.

Another useful clause (although the writer is unaware that it has ever been tested judicially) provides that where, owing to lapse of time, the sum actually recovered from a judgment to which the specified rate of exchange has been applied is less, when recovered, than the amount actually owing, then the borrower agrees as a separate covenant to pay the difference. For example, if the debtor owes one million U.S. dollars, and this is converted for the purposes of judgment into one million two hundred thousand Canadian dollars, but at the time when recovery under the judgment is made one million U.S. dollars is now worth more than one million two hundred thousand Canadian dollars, this clause attempts to require the debtor to pay the difference. As the law now stands, even this provision cannot protect the lender entirely because by the time he is paid on his second judgment (assuming he can get one), rates of exchange may have moved against him again. But at least two tries are better than one!

73. R.S.C. 1970 . c. C.39.

74. (1978) 20 O.R. (2d) 437 (H.C.S.).

75. See Bedford v. Show (1981) 330.R. (2d) 766 (Ont. S.C. ): sind Airnemp Corp. v. Chryster Airtemp Cenada Lid. (1981) I?I D.L.R. (3d) 236 (H.C.J.I.

76. $(1979) 12$ C.P.C. 97 (B.C. S.C.).

- 11927 S.C.R. $\mathbf{4} 20$.

78. See MerLead and Osecholf :. Geoservices North Amenca Lid. unreported. Feb. I. 1983. No. 128947. 1 Alta. Q.8.1. 


\title{
XVI. CANADA OIL AND GAS ACT
}

The Canada Oil and Gas Act ${ }^{79}$ contains several provisions which are relevant to a bank which lends to a borrower on the strength of security on oil and gas rights in "Canada Lands", a term which is statutorily defined to include the Yukon and Northwest Territories, Sable Island, and the offshore Canadian areas.

In the first place, it appears that the Minister must approve the loan agreement. Section S2(1) provides:

\begin{abstract}
Where an iatereat holder other than one to which Section 39 applies (the Crown or Pesto-Canada) proposes to enter iato an agreement or arrangemeas chas may result in a chansicr. assignment or other dipposition of an interen or a share in an interean. the interes holder shall gve notice of such agreement of smangement to the Mininter, togatber with a copy of the apreesnest or arrangement or, if the Misiaser approver, a summary of is terme and conditions, and no such agrement or amangement shall have agy force or effeet with respex to such tramefes, ascignment of other dispostion until it is spproved of deaned to be approved under this Section.
\end{abstract}

It is clear that a loan agreement is an agreement that "may result in a transfer. assignment or other disposition of an interest or a share in an interest" in Canada Lands. If the Minister does not approve such an agreement, he has power under Section S2(3) to prohibit the agreement, or to approve it subject to such terms arid conditions as he considers appropriate.

The second provision of major importance to a lender is Section 23, which empowers the Minister to transfer to the Crown a share in the production licence equal to the difference between fifty percent and the actual Canadian ownership rate of the interest owner. A point of note in relation to Section 23 is that it appears from the wording of Section 23(5) and the definitions of "interest owner" and "interest holder" that, where there are several "interest holders" who together constitute the "interest owner" of a production licence. all of the interest holders run the risk of having their shares in the production licence cut back where the Canadian ownership rate of any one of them falls below fifty percent. However, the wording of Section 23(5) is less than clear:

\begin{abstract}
Whese a share is a production licence is reserved to or uranderred to and vested in Her Majesty in right of Cansedn under suberection (1) or (2), the strure beld in a production ticence or that would. but for any

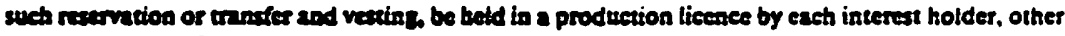
thas a deaigated Crown corportion to the extent thas it holds a Crown stare or the Ministes holding a sturere on behnif of Her Majery in rietht of Canadh. shall be reduced by the product of the share so rasued or tranderrud and vested and the peremenge equivaleat of the quotient obtained by dividing

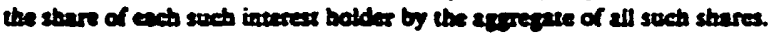

If the words "each interest holder" where they first occur in Section 23(5) are construed as referring only to those interest holders whose Canadian ownership rates fall below fifty percent, then the statute can be read so as to confine the reduction in interest to those interest holders only. A difficulty with this interpretation, however, is that Sections 23(1) and 23(2) refer to a drop below fifty percent of the Canadian ownership rate of the "interest owner", a phrase which is defined to mean "the interest holder who holds an interest or the group of interest holders who hold all of the shares in an interest". It is 
clear, therefore, that Section 23 comes into play where the Canadian ownership rate of all interest hoiders taken as a group falls below fifty percent.

Where a share of a production licence is transferred to the Crown, that share is taken free of encumbrances, although the Act specifically preserves the debts for which encumbrances were security.

A lender should also be aware that the progress of development of Canada Lands, and the borrower's consequent need for funds, may be governed by "drilling orders" issued by the Minister. The Minister has the power under Section $\mathbf{4 5}$ to direct the drilling of up to three wells at a time on any Canada Lands in respect of which a "declaration of significant discovery" has been made.

\section{APPENDIX}

\section{CHECKLIST FOR COMMERCIAL LOAN AGREEMENTS}

\section{DOCUMENTATION}
A. COMMITMENT LETTER
B. LOAN AGREEMENT

II. TYPES OF LOANS
A. REVOLVING LOAN
B. TERM LOAN
C. INTERIM LOAN

III. TERMS AND CONDITIONS

\section{A. PRINCIPAL AMOUNT}

1. currency; convertible to another currency at the option of lender/ borrower

2. clause to protect the lender from a change in law or regulation affecting the availability of funds in the currency loaned or the cost of maintaining the loan in that currency (including discretionary conversion by lender to a different currency)

3. any hedging requirements for foreign currency loan stipulated by the lender

4. clause for converting foreign currency loan into Canadian dollars in the case of default and legal judgment; indemnification by borrower against lender's loss on conversion

5. maximum amount of loan; result if exchange rate variations cause maximum to be exceeded

B. AVAILABILITY

1. direct advances

2. bankers' acceptances

3. letters of credit or other commercial guarantees

4. convertibility between 1 and 2

C. INTEREST

1. fixed rate

2. floating rate in relation to the prime rate of a specific bank or other 
lender, average of several prime rates. L.S. dollar base rate. London Interbank Offered Rate (LIBOR)

3. formulation of "prime" or "base" rate

4. $360 / 365$ or $366 / 365$ day years

5. convertibility between fixed and floating or between different loating rates

6. before and after maturity or demand and before and after defiult or judgment

7. interest on interest

8. interest after default or interest on interest at the same rate or penalty rate

9. calculation of interest; term and amortization period

D. MATURITY AND REPAYMENT

1. demand

2. term with or without instalments

3. payment of interest

4. blended or not

E. EVIDENCE OF INDEBTEDNESS

1. demand note as evidence, whether demand or term loan

2. term note

3. single (grid) note or separate notes for each advance under a credit

4. receipt of advance acknowledged, and promise to pay contained. in loan agreement only

5. lender's accounts as evidence

F. PREPAYMENT

1. Option to borrower, in whole or in part, specific time or from time to time

2. with or without prior notice

3. penalty or bonus

4. application to principal in inverse order of maturity (or other specified order)

5. no re-borrowing of prepayments

G. COMMIIMENT OR STAND-BY FEE

1. commitment fee, for availability of funds prior to disbursement

2. stand-by fee, for continued availability of the undrawn portion of the credit

3. right of the borrower to reduce the commitment and the fees

H. SECURITY

1. debenture secured by fixed/floating charges under trust deed

2. pledge agreement for debenture, other securities or cash

3. direct or collateral mortgage (real estate or chattels)

4. guarantees

5. assignment of insurance

6. acknowledgment of lender as loss payee

7. assignment of take-out loan commitment

8. assignment of government grants

9. assignment of material contracts

10. sections 177 or 178 of the Bank Act

11. assignment of accounts receivable, rentals or moneys due under specific contract (e.g. gas sales contract) 
12. notice to payor of assignment of contracts

13. completion guarantees and deficiency agreement (building contract)

14. subordination and postponement of shareholders loans and advances

15. negative pledge

16. covenant to give further security or foreign form of security at reasonable request of lender

I. DRAWDOWN REQUIREMENTS

1. opinion of counsel and certificates/statutory declarations of officers

2. delivery of hotes and agreement

3. delivery of prior drawdown notice

4. security documents executed and registered

5. representations and warranties are true

6. no event of default

7. all requisite approvals have been obtained

8. compliance with drawdown procedure (construction loan) (Builders' Lien Act)

9. particulars of authorized signatories

J. REPRESENTATIONS AND WARRANTIES

1. corporate existence, good standing and qualification to own assets and carry on business

2. corporate and other authority to borrow and grant security

3. sufficiency of corporate action taken

4. incumbency of officers

5. loan agreement valid and binding

6. agreements creating security for the loan valid and binding

7. no contrary by-law, unanimous shareholders' agreement or other agreement or statute

8. no filings required to perfect obligations under agreement

9. clear (or other acceptable to lender) title to all property and assets

10. pending litigation, arbitration or regulatory proceedings

11. no event of default under this or other loan document

12. accuracy of financial statements

13. no material adverse change since last financial statements

14. filing of returns and payment of taxes

15. location of principal place of business

16. good standing of all material agreements

17. no withholding tax on interest

K. POSITIVE COVENANTS

1. use of proceeds

2. repayment of loan; currency and place of repayment

3. tinancial requirements:
(a) maintenance of working capital
(b) tangible net worth
(c) interest coverage

4. delivery of financial statements

5. delivery of periodic evaluations of assets 
6. notice of any event of default or any event which. on a lapse of time or notice or both, would become an event of default

7. notice of any matter that has resulted or might result in a material adverse change in the borrower's financial condition or operations

8. periodic certificates of compliance and non-default

9. reimbursement for costs and expenses

10. perfection of security (further assurances)

11. operation of business:

(a) maintain corporate existence, business and properties: compliance with laws; obtain and maintain regulatory approvals

(b) payment of obligations other than payments being disputed in good faith or being contested by appropriate proceedings

(c) maintain adequate insurance

(d) accounting practices and maintenance of records

12 sale of capital assets and application of proceeds to repayment of loan or replacement of assets, etc.

13. inspection of books and assets

14. payment of taxes

\section{NEGATIVE COVENANTS}

1. debt to equity ratio

2. payment of dividends or other distributions to shareholders (except stock dividends)

3. purchase of shares

4. liquidation or dissolution, merger or amalgamation

5. additional debt, current or long-term

6. transactions affecting assets:
(a) encumbrances
(b) sale of assets
(c) acquisition of assets
(d) sale/leaseback

7. working capital

8. guarantees and other similar liabilities

9. advances and loans to others

10. payment of certain indebtedness

11. purchase or sale agreements

12. salaries or consultants' fees

13. non-arm's length

14. capital expenditures

15. leases

16. permitted investments

17. modification, cancellation or waiver of certain agreements

18. deferred compensation

19. sale of accounts receivable

20. conditional sale agreements

21. purchase money mortgages

22. restrictions on business

M. EVENTS OF DEFAULT

1. nonpayment of principal

2. nonpayment of interest 
3. inaccurancy of representations or warranties. certificates, or documents

4. default in positive or negative covenants

5. default in other obligations

6. cross default under other loan obligations

7. material adverse change

8. guarantees. security documents or material agreements becoming ineffective or in default

9. management or control change

10. involuntary liens

11. judgments

12. bankruptcy proceedings

13. acceleration of debt

14. notice requirements and delay to cure

15. lender's options on default

16. right of set-off

N. MISCELLANEOUS

1. notices to be in writing

2. remedies cumulative

3. invalidity of any provision

4. assignability

5. whole agreement

6. governing law

7. execution in counterparts and effective date

8. descriptive headings and index

9. survival of representations and warranties

10. submission to jurisdiction

11. legal and other fees for preparation, operation or enforcement of agreement

12. interpretation

13. judgment currency 